\title{
The Effects of Economic Growth and Foreign Direct Investment on Air Transportation: Evidence from Turkey
}

\author{
Salih Kalayci ${ }^{1} \&$ Gozde Yanginlar $^{2}$ \\ ${ }^{1}$ Institute of Social Sciences, Bursa Technical University, Bursa, Turkey \\ ${ }^{2}$ Institute of Social Sciences, Beykent University, Istanbul, Turkey \\ Correspondence: Salih Kalayci, Institute of Social Sciences, Bursa Technical University, Turkey. Tel: \\ 90-532-782-8990. E-mail: salih.kalayci@btu.edu.tr
}

Received: February 12, 2016

Accepted: February 22, 2016

Online Published: February 25, 2016

doi: 10.5539/ibr.v9n3p154

URL: http://dx.doi.org/10.5539/ibr.v9n3p154

\begin{abstract}
The major goal of this research paper is to investigate the relationship among Turkish Economic growth, airway transportation and FDI. Several research results consistent with this papers finding and it has been founded that the economic growth plays a crucial role in air transportation by implementing econometrical models including Multiple Linear Regression (MLR), Johansen co-integration test and VAR model. The variables have been put into the Vector Autoregressive Model (VAR) and Johansen co-integration test. According to the test result of Johansen co-integration test there is a long-term relationship between the variables of GDP, FDI and air transportation. According to the both variance decomposition and Impulse Response analysis, the effect of GDP is found to increase air transportation more than the FDI. Finally, the contribution of Turkish economy to civil aviation seems significant which is consistent with this paper's research results.
\end{abstract}

Keywords: multivariable linear regression (MLR), ADF unit root test, Johansen co-integration test, vector autoregressive model, impulse response, variance decomposition, economic growth, FDI, air transportation

\section{Introduction}

Economic growth and passenger airline service have mutual effects on each other by a series of mutual causality feedback connection. Civil aviation offers a business opportunity in air transportation sector and ensures wider socioeconomic interests via its potential in order to permit exact types of activities in a domestic economy. Thus, the existence of civil aviation services has widened by the scope of economic activities effectively and efficiently in terms of contributing to regional economic development and its stability. Air logistics infrastructure manages the economic development with lots of ways. The first contribution of supporting air transportation is raising the demand for products and services. The second significant contribution is decreasing airway turnaround cycle and for that reason the passengers gain from time and save cost. As long as the economies continue to be influenced by expanding globalization, the function of civil aviation has become incrementally crucial. Logistics sector in general and civil aviation in particular, is a significant element in perceiving the economic potential of a country. That does not mean that the only transportation sector leads the economic growth and its essential parameters likewise, the economic growth also leads to trigger the raised and much better logistics infrastructure. Therefore, there is a substantial correlation among civil aviation and economic development. Thus, a mutual relationship exists between two variables.

There are so many academic researches regarding the relationship between long-term economic development and air transportation. The connection among the growth of air transportation and its contributions to the both regional and whole countries economy is one of the popular issues in the academic literature. The growth of a metropolitan region in consequence of civil aviation and its prospects for next years is a topic of actual concern (Goetz, 1992).

According to the supply side theory, the execution of logistics infrastructure and accessibility manages to civil aviation and economic growth act as a factory for regional enterprise. But, with respect to the issue of demand-side theory, economic growth specifies necessity of transportation and its services. The question of whether demand side or supply side impacts are more significant stands largely unsettled (Mukkala \& Tervo, 2013). 
The paper is consisting of 4 sections and the structure of this work is as follows: Section 1 includes general information about the relationship between GDP and civil aviation and some researcher's works. Section 2 focus more on the discussions and main point of the academician's research results which is combined with this paper's findings. Section 3 is mostly concentrate on the effects of Turkey's GDP and FDI on air transportation by implementing econometrical methods including VAR, impulse response, variance decomposition, Johansen co-integration test and MLR. Section 4 concludes and interprets the findings of this paper by determining the difference and common point of other works in the academic literature.

\section{Literature Review}

Kasarda and Green (2005) expressed that civil aviation, which is utilized by all part of business, is often demonstrated as a locomotive of economic development for so many countries. Besides, air transportation tends to lead to total export and import of any country and a higher GDP. Mody and Wang (1997) investigated the components of coastal China's development by implementing panel data analysis for 23 main sectors among the years between 1985-1989 and determined that the transportation infrastructure was a dynamic of economic development. A developing body of their research paper is starting to address the significant relationship among economic growth and civil aviation of countries. Fleming and Ghobrial (1994) investigated the components of domestic air transportation demand in the southeastern U.S.A by appraising the exact economic practices on domestic air travel and they proved the empirical relationship between the relevant variables. Banister and Berechman (2003) draw a general perspective that defines the linkage among the economic development and air logistics. According to their findings, enhanced transportation infrastructure decreases distance and cost and raises traffic volume. Mukkala and Tervo (2013) expressed that civil aviation carries a great important role in acceleration of growth in remote territories. Logistics accessibility is one of different prerequisites for a country's raised development and capacity to competition. Air travel ensures a timely and confidential way by which to transfer people, products and services from one region to another. Demurger (2001) examined the relationship among logistics infrastructure and economic development in China by implementing panel data analysis with 24 sample size for Chinese cities from the years of 1985 to 1998, and found that transportation income triggered the economic development. According to Hong (2007) better infrastructure provides more FDI which is broadly regarded as a significant catalyst of economic development in China. Helling (1997) handled the employment dimension of economy and gave proof regarding how transportation system also ensures the job accessibility and quality of life and according to her it makes an area attractive to labors and employers.

Civil aviation sector built up with a great annual rate more than 16\% during the years of 1980-1997 in China. However, it was decreased to $10 \%$ in 1997 and 1998. The great growth of air transportation throughout the recent two decades in between 1980-1997 in China was contributed to faster economic growth through applying economic reform and low price policy by the government. The income rises under favor of air transportation and as a result the market share of civil aviation sector was increased as well. Thus, the air transportation became more preferable and popular (Jin, Wang, \& Liu, 2004).

In addition, civil aviation affects the economy by ensuring staffing and by enabling influences containing access to markets, capital, worker, ideas, knowledge, labor supply, opportunity, and resources at the macroeconomic level. In turn the economy ensures capital and creates demand for air transportation sector (Ishutkina \& Hansman, 2008).

Hong, Chu, and Wang (2011) claims that the effects of transportation infrastructure on economic development should be analyzed at different locations separately. In huge countries in terms of populations such as China, the significant regional differences exist. That means that they defend micro researches instead of macro researches. Furthermore, transportation facilities may have separated the effects on economic development across regions. To sum up, majority of available researches considers a linear relationship among transportation and economic growth in the literature. However, the transportation infrastructure gains such as time saving may be capitalized via agglomeration impacts which imply a nonlinear relationship among economic development and transportation infrastructure.

The Causal relationships between economic development and air transportation create different policy implications. For instance, if a directional causality exists from air transportation to economic development, air carriage growth would be constructive for economic development. On the other hand, if directional causality becomes available from economic development to air transportation, it may be demonstrated that growing air transportation demand may be applied with little or no impacts on economic development. Moreover, if directional causality carried out among air logistics growth and economic development, it is both essential and feasible to enhance the economic growth and air carriage at the same time (Chang \& Chang, 2009). 
The other crucial contribution is ensured by Ashford (1994) who recommended that civil aviation sector should be placed in the widen area of the changing economic perspectives. He discussed that the traffic intensity at an airport is excessively volatile due to the highly competitive strategies of the main air transport firms.

The academicians have questioned whether the distance should matter at all; discussing that advances in telecommunications and reducing transportation expenditures should decrease the effect of distance on both foreign direct investment and trade activities. In this context, there have been fast advances in telecommunication facilities and reduce the communication costs. Birgun and Gungor (2014) lay great stress on the distance of factory to the center of the cities in terms of transportation cost and contribution to economic growth. They took into account several factors in order to select appropriate point for establishing production plant including population, labor cost, transportation and unemployment rate by implementing operations research applications and algorithms.

Daniels and Ruhr (2014) ascertain that the United States of America's air logistics cost has a positive and empirically important relationship with their total FDI. In other words, there is an outstanding relationship between FDI and trade flows. The research result of this paper at Table 8 below is consistent with their findings in terms of long term relationship. Kimura, Ando, and Fujii (2003) elaborated on the results of forecasting ad valorem equivalents of barriers to FDI in the seaway and civil aviation market in Russia and they found a strict relationship between them which is also consistent with this paper's findings.

Majority of working papers finalize that investment of government in transportation sector has a great and massive impact on output. In this research paper, we address a fresh look at the significant findings regarding the relationship between air transportation and economic growth through a view to offering suggestions regarding how the topic may be elaborated in terms of government policy. Thus, it would be better for governments when they intend to enhance an efficient and effective economic policy and airfreight.

\section{Methodology and Data Analysis}

The major goal of this study is determining the effect of macroeconomic variables on air transportation in between 1974-2014 in Turkey which is a gap in the literature. The main questions are: Does Turkey's economic growth has a significant impact on Air Transport (Passengers Carried)? Does Turkey's FDI rate have a significant impact on Air Transport (Passengers Carried)? The data was retrieved from Worldbank.org (See Table 10). Logarithm were not applied to the data and the sample size is 41 which is more than " $\mathrm{n}>30$ " to make it parametrically test. In order to answer the research questions about both their long-run relationship and impacts of the independent variables (GDP and FDI) on air transportation, the MLR and Johansen co-integration tests were used conscientiously.

Table 1. The effects of Turkey's GDP and FDI on air transport (passengers carried) in between 1974-2014 (MLR)

\begin{tabular}{llccc}
\hline \multicolumn{2}{c}{ Dependent Variable: AIR_TRNS } & Sample Size 1974-2014 & \multicolumn{2}{c}{ Included observations: 41 } \\
\hline Variable & Coefficient & Std. Error & t-Statistics & Prob. \\
\hline GDP & $6.12 \mathrm{E}-10$ & $9.05 \mathrm{E}-11$ & 6.763508 & 0.0000 \\
FDI & 0.000376 & 0.000392 & 0.958220 & 0.3440 \\
C & 235149.6 & 2201442 & 0.106816 & 0.9155 \\
AR(1) & 0.714056 & 0.078714 & 9.071528 & 0.0000 \\
\hline R-Squared & 0.755746, Durbin Watson stat 1.761561, Adjusted R-Squared 0.539087, Inverted AR Roots & 0.71 \\
\hline
\end{tabular}

The Multivariable Linear Regression (MLR) has to be applied to answer the research questions at Table 1. The E-views program was used in order to implement the econometrical tests such as VAR model, impulse response and variance decomposition. "AR(1)" was added as a code at program to the model to avert autocorrelation so that residuals were distributed randomly.

GDP and FDI were defined as independent variable to find out the impact on air transport (passengers carried) and the results indicated that there is notable effect of GDP on Turkey's air transportation which is founded 0.0000. In other respects, the code of @ trend is added to the econometric model through E-views program in order to comprehend that there is counterfeit regression or not. The result of the @ trend is more than 0.05 which demonstrates that there is no falsified relationship among GDP and air transportation. However there is no effect of FDI on air transport (passengers carried). 
Table 2. ADF test results for air transport before converting I (0) to I (1) (non-stationary)

\begin{tabular}{llcc}
\hline $\begin{array}{l}\text { Null Hypothesis: AIR_TRNS has a unit root } \\
\text { Lag Length: } 0 \text { (Automatic-based on SIC, maxlag =9) } \\
\text { Exogenous: Constant }\end{array}$ & & & \\
\hline & & $\underline{\text { t-Statistic }}$ & $\underline{\text { Prob.* }^{*}}$ \\
Augmented Dickey-Fuller test statistic & $1 \%$ level & 1.117581 & 0.9970 \\
Test critical values: & $5 \%$ level & -3.605593 & \\
& $10 \%$ level & -2.936942 & \\
\end{tabular}

The ADF test results of air transportation indicate that the series are not stationary. The score of prob is 0.9970 and it must be less than 0.05 . Therefore, the series have to be stationary to apply econometrical analysis.

Table 3. ADF test results for GDP before converting I (0) to I (1) (non-stationary)

\begin{tabular}{llll}
\hline $\begin{array}{l}\text { Null Hypothesis: GDP has a unit root } \\
\text { Lag Length: } 0 \text { (Automatic - based on SIC, maxlag=9) } \\
\text { Exogenous: Constant }\end{array}$ & & & \\
\hline & & $\underline{\mathrm{t}-\text { Statistic }}$ & $\underline{\text { Prob.* }}$ \\
Augmented Dickey-Fuller test statistic & $1 \%$ level & -1.304860 & 0.6180 \\
Test critical values: & $5 \%$ level & -3.605593 & \\
& $10 \%$ level & -2.936942 & \\
& & -2.606857 & \\
\hline
\end{tabular}

The ADF test results of GDP demonstrate that the series are not stationary. The score of prob is 0.6180 and it must be less than 0.05 . For this reason, the series have to be stationary to apply econometrical analysis.

Table 4. ADF test results for FDI before converting I (0) to I (1) (non-stationary)

\begin{tabular}{|c|c|c|c|}
\hline \multicolumn{4}{|c|}{$\begin{array}{l}\text { Null Hypothesis: FDI has a unit root } \\
\text { Lag Length: } 4 \text { (Automatic - based on SIC, maxlag=9) } \\
\text { Exogenous: Constant }\end{array}$} \\
\hline & & $\underline{\mathrm{t}-\text { Statistic }}$ & Prob.* \\
\hline Augmented Dickey-Fuller test statistic & & -0.928144 & 0.7689 \\
\hline \multirow[t]{3}{*}{ Test critical values: } & $1 \%$ level & -3.605593 & \\
\hline & $5 \%$ level & -2.936942 & \\
\hline & $10 \%$ level & -2.606857 & \\
\hline
\end{tabular}

The ADF test results of FDI show that the series are not stationary. The score of prob is 0.7689 and it must be less than 0.05 . Therefore, the series have to be stationary to apply econometrical analysis.

The Results of ADF tests for GDP, FDI and air transportation indicate that the dataset are not stationary (See Table 2, 3, 4). For this reason, the E-Views program's code was used to convert the data non-stationary to stationary. The codes of the program are follows; genr air_trns $1=$ air_trns-air_trns $(-1)$, genr fdi $=f d i$-fdi $(-1)$ and $g e n r g d p 1=g d p-g d p(-1)$. After converting the data from non-stationary "I (0)" to the stationary "I (1)" (See Table 5, 6, 7), the variables have been replaced into the Vector Autoregressive Model (VAR) and Johansen co-integration test. According to the test result of Johansen co-integration test there is a long-term relationship among the variables of GDP, FDI and air transportation (See Table 8).

The inverse root of AR characteristic polynomials test corrected all the specifications of root means remained within the circle which verified that the VAR model is stationary at lag 1 and lag 2 (See Figure 1 below). Thus, both impulse response and variance decomposition tests can be done by using econometrical program. According to the results of Table 9 (variance decomposition tests) and Figure 2 (Impulse Response Analysis), the effect of GDP is found to increase air transportation more than the FDI. 
Table 5. ADF test results for air transport after converting I (0) to I (1) (stationary)

\begin{tabular}{llcc}
\hline Null Hypothesis: AIR_TRNS1 has a unit root & & \\
Lag Length: 0 (Automatic - based on SIC, maxlag=9) \\
Exogenous: Constant
\end{tabular}

After converting the series of air transportation from I (0) non-stationary to I (1) stationary, the empirical analysis can be done. The result of "prob $0.0000 "$ demonstrates that the series are stationary.

Table 6. ADF test results for GDP after converting I (0) to I (1) (stationary)

\begin{tabular}{llll}
\hline Null Hypothesis: GDP1 has a unit root & & & \\
Lag Length: 0 (Automatic - based on SIC, maxlag=9) \\
Exogenous: Constant
\end{tabular}

After converting the series of GDP from I (0) non-stationary to I (1) stationary, the empirical analysis can be done. The result of "prob 0.0000 " indicates that the series are stationary.

Table 7. ADF test results for FDI after converting I (0) to I (1) (stationary)

\begin{tabular}{|c|c|c|c|}
\hline \multicolumn{4}{|c|}{$\begin{array}{l}\text { Null Hypothesis: FDI1 has a unit root } \\
\text { Lag Length: } 0 \text { (Automatic - based on SIC, maxlag=9) } \\
\text { Exogenous: Constant }\end{array}$} \\
\hline & & $\underline{\mathrm{t} \text {-Statistic }}$ & Prob.* \\
\hline Augmented Dickey-Fuller test statistic & & -9.021704 & 0.0000 \\
\hline \multirow[t]{3}{*}{ Test critical values: } & $1 \%$ level & -3.610453 & \\
\hline & $5 \%$ level & -2.938987 & \\
\hline & $10 \%$ level & -2.607932 & \\
\hline
\end{tabular}

After converting the series of FDI from I (0) non-stationary to I (1) stationary, the empirical analysis can be done. The result of "prob 0.0000 " indicates that the series are stationary.

Table 8. Johansen co-integration test (The long-run relationship between GDP, FDI and air transportation)

\begin{tabular}{ccccc}
\hline Hypothesized No. of CE(s) & Eigenvalue & Trace Statistic & 0.05 Critical Value & Prob.** \\
\hline None $*$ & 0.547679 & 67.78807 & 29.79707 & 0.0000 \\
At most 1 $*$ & 0.442500 & 37.64024 & 15.49471 & 0.0000 \\
At most 2 $*$ & 0.333849 & 15.43708 & 3.841466 & 0.0001 \\
\hline
\end{tabular}

According to the test result of Johansen co-integration test there is a long-term relationship among the variables of GDP, FDI and air transportation. The results of prob seems as 0.0000 which proves the long-run stable relationship between variables. 


\section{Inverse Roots of AR Characteristic Polynomial}

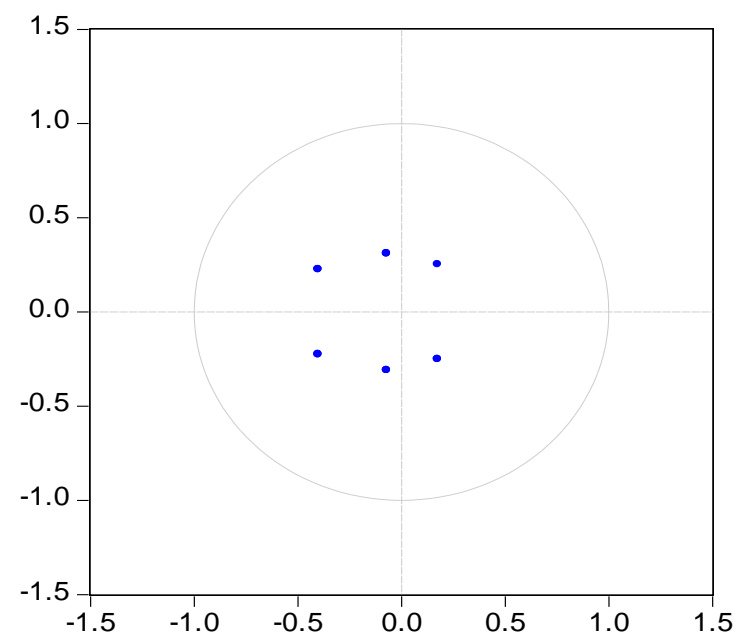

Figure 1. The vector autoregressive (VAR) model

The inverse root of AR characteristic polynomials test corrected all the specifications of root means fell within the circle at figure 1 above which proves that the VAR model is stationary at lag 1 and lag 2 . Thus, both impulse response and variance decomposition tests can be done by implementing econometrical program. Besides, Vector Autoregressive Test demonstrates that the optimal lag structure is 1 . The sample size is 41 for this reason Akaike Information Criteria (AIC) was used. Furthermore, since optimal lag value obtained as 1 in VAR, the residuals's first lagged value was found to take into account the long term effect of GDP and FDI on air transportation of Turkey.

Table 9. Variance decomposition

\begin{tabular}{ccccc}
\hline Period & S. E. & AIR_TRNS1 & GDP1 & FDI1 \\
\hline 1 & 0.188546 & 100.0000 & 0.000000 & 0.000000 \\
2 & 0.201612 & 93.61690 & 0.033110 & 6.349988 \\
3 & 0.213123 & 87.00792 & 6.704525 & 6.287553 \\
4 & 0.214987 & 85.92260 & 7.319399 & 6.758000 \\
5 & 0.215136 & 85.80974 & 7.379755 & 6.810504 \\
6 & 0.215154 & 85.79552 & 7.394999 & 6.809484 \\
7 & 0.215157 & 85.79508 & 7.394928 & 6.809995 \\
8 & 0.215159 & 85.79464 & 7.395060 & 6.810302 \\
9 & 0.215159 & 85.79437 & 7.395207 & 6.810425 \\
10 & 0.215159 & 85.79428 & 7.395268 & 6.810447 \\
\hline
\end{tabular}

According to the both variance decomposition and Impulse Response analysis, the effect of GDP is found to increase air transportation more than the FDI. The result of GDP is 7.39 at table 9 above which is bigger than the result of FDI. 
Response of AIR_TRNS1 to Cholesky

One S.D. Innovations

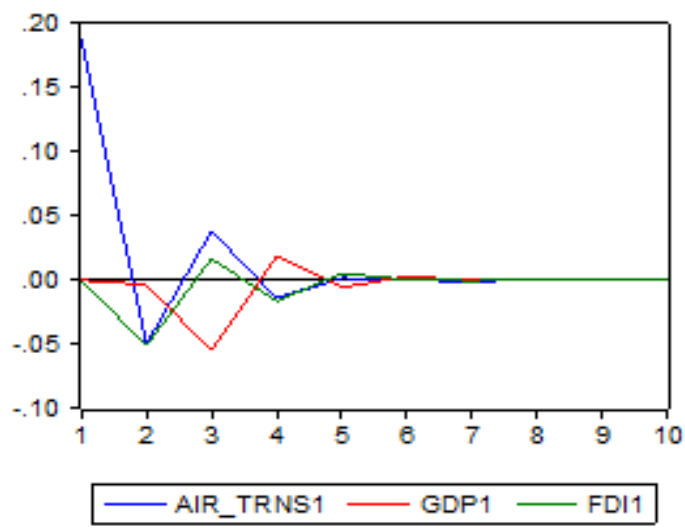

Response of GDP1 to Cholesky

One S.D. Innovations

Figure 2. Impulse response analysis

The fluctuation of GDP in red line seems more comparing with FDI in green line at Figure 2 above. Therefore, in case of shock, the impact of GDP on air transportation is more than FDI.

\section{Conclusion}

This paper's research results reveal that there is a long-term relationship between GDP, FDI and civil aviation according to the Johansen co-integration test. The findings are associated with domestic economic interests such as employment, flow of income that airport's operations put into the domestic economy. Furthermore, the government collects more taxation revenue and competition increases within the air transportation market. For example, more than 20 companies enter into rivalry with each other including Turkish Airlines, Pegasus Airlines, Onur Air, Atlasglobal, Bora Jet and so on. For this reason, the passengers find an opportunity to obtain cheaper flight ticket due to sharp competition within the market. As a result, the transportation capacity of Turkey increased from 1795100 in 1974 to 92624864 in 2014. Thus, the contribution of Turkish economy to civil aviation seems remarkable which is consistent with this paper's research results. Button and Taylor (2000) urges upon the benefits of the air logistics to USA's economy involving employment and collecting more taxes. They prove longer term impact between air transportation and economic growth.

The empirical proof of this study demonstrates that, there is a long-term relationship among the variables of GDP, FDI and air transportation. According to the both variance decomposition and Impulse Response analysis, the effect of GDP is found to increase air transportation more than the FDI. According to Hong (2007) better transportation infrastructure provides more FDI which is resembled with our results of co-integration test. However, considering the direction of the relationship in terms of FDI to air transportation in Turkey, there is no impact of FDI on air transportation which is rejected by MLR analysis. In addition, there is significant impact of GDP on air transportation in Turkey in the period of 1974-2014 by implementing econometrical model.

Table 10. Data of Turkey (GDP, air transport, passengers carried and FDI)

\begin{tabular}{cccc}
\hline Year & GDP Current US \$ & Air Transport, Passengers Carried & FDI BoP Current US \$ \\
\hline 1974 & 35599913836 & 1795100 & 64000000 \\
1975 & 44633707242 & 1777800 & 114000000 \\
1976 & 51280134554 & 2427300 & 10000000 \\
1977 & 58676813687 & 2751700 & 27000000 \\
1978 & 65147022485 & 2221500 & 34000000 \\
1979 & 89394085658 & 2458400 & 75000000 \\
1980 & 68789289565 & 1253700 & 18000000 \\
1981 & 71040020140 & 2071300 & 95000000 \\
1982 & 64546332580 & 2094600 & 55000000 \\
\hline
\end{tabular}




\begin{tabular}{|c|c|c|c|}
\hline 1983 & 61678280115 & 2233600 & 46000000 \\
\hline 1984 & 59989909457 & 2575400 & 113000000 \\
\hline 1985 & 67234948264 & 2508000 & 99000000 \\
\hline 1986 & 75728009962 & 2721900 & 125000000 \\
\hline 1987 & 87172789528 & 3260900 & 115000000 \\
\hline 1988 & 90852814004 & 3497300 & 354000000 \\
\hline 1989 & 107143348667 & 3792300 & 663000000 \\
\hline 1990 & 150676291094 & 4337100 & 684000000 \\
\hline 1991 & 150027833333 & 3160000 & 810000000 \\
\hline 1992 & 158459130435 & 4958600 & 844000000 \\
\hline 1993 & 180169736364 & 6076800 & 636000000 \\
\hline 1994 & 130690172297 & 6871600 & 608000000 \\
\hline 1995 & 169485941048 & 7749000 & 885000000 \\
\hline 1996 & 181475555283 & 8463900 & 722000000 \\
\hline 1997 & 189834649111 & 9379900 & 805000000 \\
\hline 1998 & 269287100882 & 9949300 & 940000000 \\
\hline 1999 & 249751469675 & 10097300 & 783000000 \\
\hline 2000 & 266567532790 & 12187891 & 982000000 \\
\hline 2001 & 196005289736 & 10603908 & 3352000000 \\
\hline 2002 & 232534560443 & 10686877 & 1082000000 \\
\hline 2003 & 303005303085 & 10745444 & 1702000000 \\
\hline 2004 & 392166275623 & 14275835 & 2785000000 \\
\hline 2005 & 482979839089 & 16943828 & 10031000000 \\
\hline 2006 & 530900094645 & 19361415 & 20185000000 \\
\hline 2007 & 647155131936 & 22895275 & 22047000000 \\
\hline 2008 & 730337495736 & 25505092 & 19851000000 \\
\hline 2009 & 614553921806 & 31339441 & 8585000000 \\
\hline 2010 & 731168051903 & 45665249 & 9099000000 \\
\hline 2011 & 774754155284 & 53500303 & 16176000000 \\
\hline 2012 & 788863301670 & 63350312 & 13282000000 \\
\hline 2013 & 823242587404 & 82647519 & 12457000000 \\
\hline 2014 & 798429233036 & 92624864 & 12765000000 \\
\hline
\end{tabular}

Source: World Bank (2016).

\section{References}

Ashford, N. (1994). Airport Management in a Changing Economic Climate. Transportation Planning and Technology, 18(1), 57-63. http://dx.doi.org/10.1080/03081069408717533

Banister, D., \& Berechman, J. (2003). Transport Investment and Economic Development. Routledge.

Birgun, S., \& Gungor, C. (2014). A Multi-Criteria Call Center Site Selection by Hierarchy Grey Relational Analysis. Journal of Aeronautics and Space Technologies, 7(1), 45-52.

Button, K., \& Taylor, S. (2000). International Air Transportation and Economic Development. Journal of Air Transport Management, 6(4), 209-222. http://dx.doi.org/10.1016/S0969-6997(00)00015-6

Chang, Y. H., \& Chang, Y. W. (2009). Air Cargo Expansion and Economic Growth: Finding the Empirical Link. Journal of Air Transport Management, 15(5), 264-265.

Daniels, J. P., \& Ruhr, M. (2014). Transportation costs and US Manufacturing FDI. Review of International Economics, 22(2), 299-309. http://dx.doi.org/10.1111/roie.12110

Demurger, S. (2001). Infrastructure Development and Economic Growth: An Explanation for Regional Disparities in China? Journal of Comparative Economics, 29(1), 95-117. http://dx.doi.org/10.1006/jeec.2000.1693

Fleming, K., \& Ghobrial, A. (1994). An Analysis of the Determinants of Regional Air Travel Demand. Transportation Planning and Technology, 18(1), 37-44. http://dx.doi.org/10.1080/03081069408717531

Goetz, A. R. (1992). Air Passenger Transportation and Growth in the US Urban System, 1950-1987. Growth and 
Change, 23(2), 217-238. http://dx.doi.org/10.1111/j.1468-2257.1992.tb00580.x

Helling, A. (1997). Transportation and Economic Development. A Review. Public Works Management \& Policy, 2(1), 79-93. http://dx.doi.org/10.1177/1087724X9700200108

Hong, J. (2007). Transport and the Location of Foreign Logistics Firms: The Chinese Experience. Transportation Research Part A: Policy and Practice, 41(6), 597-609.

Hong, J., Chu, Z., \& Wang, Q. (2011). Transport Infrastructure and Regional Economic Growth: Evidence from China. Transportation, 38(5), 737-752. http://dx.doi.org/10.1007/s11116-011-9349-6

Ishutkina, M. A., \& Hansman, R. J. (2008). Analysis of Interaction between Air Transportation and Economic Activity. http://dx.doi.org/10.2514/6.2008-8888

Jin, F., Wang, F., \& Liu, Y. (2004). Geographic Patterns of Air Passenger Transport in China 1980-1998: Imprints of Economic Growth, Regional Inequality, and Network Development. The Professional Geographer, 56(4), 471-487. http://dx.doi.org/10.1111/j.0033-0124.2004.00442.x

Kasarda, J. D., \& Green, J. D. (2005). Air Cargo as An Economic Development Engine: A Note on Opportunities and Constraints. Journal of Air Transport Management, 11(6), 459-462.

Kimura, F., Ando, M., \& Fujii, T. (2004). Estimating the Ad Valorem Equivalent of Barriers to Foreign Direct Investment in the Maritime and Air Transportation Service Sectors in Russia. Retrieved from http://siteresources.Worldbank.org/INTRANETTRADE/Resources/Topics/kimura-Ando-Fujii-RussiaTransp ort. pdf

Mody, A., \& Wang, F. Y. (1997). Explaining industrial growth in coastal China: Economic reform and what else? The World Bank Economic Review, 11(2), 293-325.

Mukkala, K., \& Tervo, H. (2013). Air transportation and Regional Growth: which Way Does the Causality Run? Environment and Planning A, 45(6), 1508-1520. http://dx.doi.org/10.1068/a45298

The World Bank. (2016a). Air Transport, Passengers Carried. Retrieved from http://data.worldbank.org/indicator/IS.AIR.PSGR

The World Bank. (2016b). Foreign Direct Investment. Retrieved from http://data. worldbank.org/indicator/BX.KLT.DINV.CD.WD?page $=6$

The World Bank. (2016c). GDP (Current US \$). Retrieved from http://data.worldbank.org/indicator/NY.GDP.MKTP.CD/countries

\section{Copyrights}

Copyright for this article is retained by the author(s), with first publication rights granted to the journal.

This is an open-access article distributed under the terms and conditions of the Creative Commons Attribution license (http://creativecommons.org/licenses/by/3.0/). 